\title{
Parametric Study of The Parameters Affecting Concrete Pavement Thickness*
}

\author{
Aydın KICI ${ }^{1}$, Mesut TIĞDEMİR ${ }^{1}$, Şengül Figen KALYONCUOĞLU ${ }^{1}$
}

\begin{abstract}
Concrete pavements are the superstructure elements that can serve for a long time without deterioration. Concrete pavements are using intensively for interstate highways where heavy traffic volume is high, parking facilities, airfields and industrial facilities. One of the most important features of concrete pavements, which are widely used in interstate roads in America, is more environmentally friendly compared to flexible superstructures. This increases the need for concrete pavements in our time when sustainability is important. Because of the complex concrete properties and soil properties, the concrete pavement design is complex than expected. Due to the complexity of the designs, they were previously designed based on experiences. Subsequently, design methods with both mechanical and experimental infrastructure have been developed thanks to mechanical methods. Among these design methods, PCA 1984 and AASHTO 1993 are the most widely used for concrete pavement design. Both the PCA 1984 and the AASHTO 1993 design method are used concrete properties, subgrade reaction, and traffic characteristics as input parameters. In this study, three main parameters affecting concrete pavement thickness (concrete properties, soil reaction and traffic) were examined according to AASHTO and PCA methods. By this way, the correlation between pavement thickness and these parameters is shown. Another result obtained from this study is which parameters are more sensitive to concrete pavement thickness.
\end{abstract}

Keywords: AASHTO, concrete pavement design, parametric study, PCA.

\section{Beton Kaplama Kalınlığına Etki Eden Parametrelerin Parametrik Olarak İncelenmesi}

ÖZET: Beton kaplamalar, uzun zaman bozulmadan hizmet verebilen üstyapı elemanlarıdır. Özellikle ağır trafik yüklerinin yoğun olduğu eyaletler arası yollarda, havaalanlarında, park alanlarında, sanayi alanlarında yoğun olarak kullanılmaktadır. Özellikle Amerika'da eyaletler arası yollarda yaygın olarak kullanılan beton yolların en önemli özelliklerinden biri de esnek üstyapı elemanıyla karşıllaştırıldığında daha çevreci oluşudur. Bu durum, sürdürülebilirliğin önem kazandığı çağımızda beton yol kaplamalarına duyulan ihtiyacı arttırmaktadır. Karmaşık beton özellikler ve zemin yapısından dolayı beton yol tasarımı beklenenden karışıktır. Beton yollar, tasarımının karmaşıklı̆̆ından dolayı, önceleri deneyimlere dayalı olarak tasarlanmışlardır. Daha sonraları, mekanik yöntemlere başvurularak hem mekanik hemde deneysel altyapıya sahip tasarım yöntemleri geliştirilmiştir. Bu tasarım metotları içersinde en yaygın olarak kullanılanlar PCA 1984 ve AASHTO 1993 tasarım metotlarıdır. Hem PCA 1984 hem de AASHTO 1993 tasarım metodunda beton özellikleri, zemin tepkisi ve trafik özellikleri girdi parametresi olarak kullanılmaktadır. Bu çalışmada, plak kalııı̆ını etki eden üç ana paratmere (beton özellikleri, zemin tepkisi ve trafik) AASHTO ve PCA metotlarına göre incelenmiştir. Bu sayede, plak kalınlığı ile bu parametreler arasındaki bağıntı gösterilmiştir. Bu çalışmadan elde edilen bir diğer sonuç, hangi parametrelerin beton plak kalınlığı üzerindeki daha hassasiyet gösterdiğidir.

Anahtar Kelimeler: AASHTO, beton plak tasarımı, parametrik çalışma, PCA.

\footnotetext{
Aydın KICI (0000-0001-9741-4995), Mesut TIĞDEMIR (0000-0002-5303-2722), Şengül Figen KALYONCUOĞLU (0000-0002-4759-9749), Süleyman Demirel University, Engineering Faculty, Civil Engineering / Transportation Department, Isparta, Türkiye Sorumlu yazar/Corresponding Author: Mesut TIĞDEMIR, mesuttigdemir@sdu.edu.tr

Bu çalışma 09-11 Ekim 2017 tarihinde Iğdır-Türkiye’de düzenlenen II. International Iğdır Symposium’unda sunulmuş ve kongre özet kitabında yayınlanmıştır.
} 


\section{INTRODUCTION}

In the 21 st century, the human population has increased considerably, technological developments have accelerated and there have been major commercial changes. These developments have increased the need for transport structures. Today, transportation is provided to a large extent with flexible pavements. However, the need for sustainable and long-lasting transportation systems has increased with today's technological developments. At this point, the rigid pavements have emerged as an alternative to the flexible pavements.

The need for concrete road pavements is increasing because of materials used in concrete production are more environmentally friendly than those used in flexible pavements. Also, concrete roads have a long life compared to other kinds of pavements (Delatte, 2014).

Owing to this high rigidity of concrete, concrete pavements transmit vehicle loads to a wider area and more homogeneously to the lower layers. Concrete pavements are using as a superstructure in street ways, highways, industrial areas, airports, parking lots etc. (Yolder and Witczak, 1975).

They have a long service life when they are planned and built in accordance with the purpose. It has a high initial construction cost but his life cycle costs are low because they require little maintenance over their service life (Delatte, 2014).

\section{MATERIALS AND METHODS}

\section{PCA 1984 And AASHTO 1993 Design Methods}

The most important part of concrete pavement design is calculate an accurate pavement thickness.

While unnecessary pavement thickness increases the cost, inadequate thickness design may cause loss of service before design life (O'Flaherty, 2002). For this reason, required importance should be given to pavement thickness design. The design of the concrete pavement thickness is a complicated process due to the complex mechanical properties of concrete and subgrade. In order to reduce this complexity, many design methods based on mechanical and experimental basis have been established. The most important of these are PCA 1984 and AASHTO 1993 design methods. Both design methods have been widely used by designers and researchers for many years (Huang, 2004).

PCA uses the maximum vertical deflections and maximum stresses which traffic load cause on the concrete pavement. The mechanically obtained values of deflection and stress are evaluated with the through charts and tables provided by PCA 1984 method (Huang, 2014).

PCA method uses two analysis, they are erosion and fatigue analysis. In fatigue analysis, the ratio between pavement stress under heavy traffic load and concrete modulus of rupture are used. This known as cumulative damage factor (CDF). If the value of CDF exceeds 1.00 , it means that the thickness is not enough and designer should increase the thickness (PCA, 1966; PCA, 1984).

The AASHTO method has been enhanced with published manuals in different years. AASHTO method is a design method based on more experimental data which obtained from AASHTO road tests.

AASHTO's guideline presented in different years has almost same concept. The AASHTO method uses the Equivalent Single Axle Load (ESAL) approach, which is used extensively by the designers for present traffic data. (Bordelon et al, 2015). Since the AASHTO method is based on both mechanical and experimental basis, it gives more accurate results.

In $\mathrm{Eq} 1 . \mathrm{W}_{8.2}$ is the 8.2 tons equivalent single axle loads, $\mathrm{P}_{\mathrm{t}}$ is the terminal serviceability index, $\mathrm{J}$ is the load transfer coefficient, $\mathrm{S}_{\mathrm{c}}$ is the modulus of rupture, $\triangle \mathrm{PSI}$ is the total change in serviceability index, $E_{c}$ is the modulus of elasticity of concrete, $k$ is the effective module of subgrade reaction, $\mathrm{S}_{0}$ is the standard deviation, $Z_{R}$ is the reliability, $C_{d}$ is the level of drainage, $\mathrm{D}$ is the pavement thickness. 


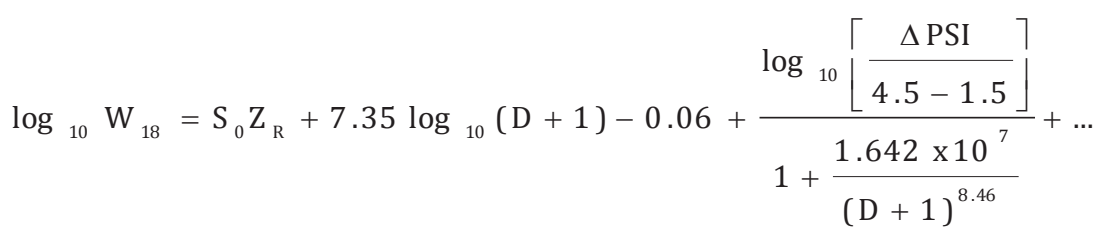

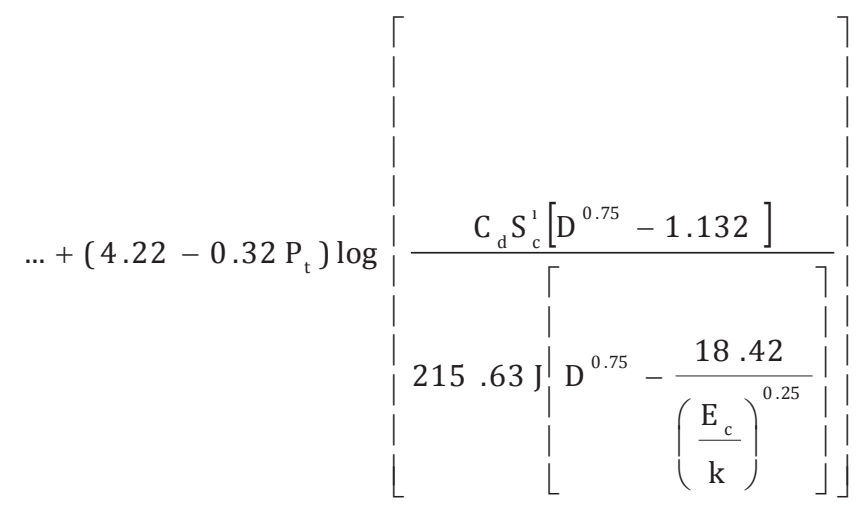

\section{Parameters Affecting Design Pavement Thickness}

Both PCA 1984 and AASHTO 1993 methods use some parameters that affect pavement thickness. Some of these parameters are same for both methods, many of the parameters used are different. For example, while the drainage is taken into account in the AASHTO 1993 method, there is no parameter representing drainage in the PCA 1984 analysis.

Concrete roads are subject to repeated traffic loads during their lifetime. These loads are the main cause of the deterioration of the pavements (Lee et al., 1997). The factors which affect pavement thickness can be grouped under three main headings. The traffic condition is the first factor affecting the concrete pavement thickness.

The number of vehicles and axle weights that will pass through the lifetime of the pavement is very important in terms of design. The effect on the design of pavement thickness heavy vehicle factor considerably high compared to other vehicles. For this reason, for the proper pavement thickness design, the heavy vehicle factor is very important. Therefore, in the PCA 1984 analysis only truck loads are considered for traffic loads. According to the type and weight of each truck axle, erosion and fatigue analyzes are performed. Analyzes were made using SDU.Pave.R software (Kic1 and Tiğdemir, 2017). As a result of these analyzes, it is determined whether the pavement thickness is sufficient.
In the AASHTO 1993 design method, the ESAL is taken into account in contrast to the PCA 1984 method. ESAL is the equivalent of 8.2 tons $(80 \mathrm{KN})$ axle weight of vehicle traffic passing through the overlay. The empirical formulas obtained from the AASHTO road tests are used to convert axle weights to the specified ESAL.

In the AASHTO 1993 method, the total damage factor is calculated by expanding each axle load with LEF. The time for these calculations is the design period. The total ESAL value found throughout the design period is one of the most important inputs of the AASHTO 1993 design method.

Another important factor in the design of concrete plate thickness is mechanical properties of concrete. Those mechanic properties of concrete are poisson ratio, modulus of elasticity, thermal expansion coefficient, compressive strength, tensile strength and flexural strength.

All concrete structures have a high resistance against pressure but a relatively low resistance against tension and bending. Repetitive vehicle loads try to bend the pavement. Concrete resists this bending stress with its flexural strength. The ratio between the flexural stress and the flexural strength characterizes the failure of the concrete.

Both the PCA 1984 and the AASHTO 1993 design method affected by the flexural strength of concrete. 
There is a strong bond between this flexural strength and the compressive strength of the concrete. In different studies over time, researchers have shown the relationship between the compressive strength and flexural strength of concrete by different experimental methods. As the flexural strength increases, the service life of the concrete will increase because the ratio between flexural strength and flexural stress decreases.

Another factor that is effective in the design of concrete pavement is soil properties. For concrete pavement design, the soil definition is usually expressed by the subgrade reaction $(\mathrm{k})$ obtained by California Bearing Test results. Both PCA and AASHTO use $\mathrm{k}$

\section{RESULTS AND DISCUSSION}

Modulus of rupture and subgrade reaction $(\mathrm{k})$ inputs are using for both PCA and AASHTO methods.

While the AASHTO method uses ESAL calculation for traffic PCA uses fatigue and erosion analyzes. For this reason, ESAL values are calculated for each truck ratio. An appropriate axle distribution was chosen to values in their design methods. The subgrade $\mathrm{k}$ module can be obtained by dividing the tension on the pavement under the unit load and deflections on the pavement.

PCA 1984 and AASHTO 1993 also use different design inputs. For example, AASHTO 1993 uses different design inputs such as design drainage coefficient, concrete modulus of elasticity and so on. Likewise, in the PCA 1984 method, whether or not the shoulder support is present or whether the joints are doweled affects the pavement thickness. Although there are different inputs in both design methods, the three basic inputs common in both method traffic, $\mathrm{k}$ modulus and modulus of rapture.

distribute the overall state of the traffic realistically for PCA analysis. The analyzes were done according to this distribution. In this view, the traffic approach that is different in the AASHTO and PCA methods has been made comparable.

A mean axle distribution has selected to represent the real condition. The selected axle distribution for PCA design was given in Table 1.

Table 1. Selected axle distribution for PCA design

\begin{tabular}{cc|cc}
\hline \multicolumn{2}{c|}{ Single Axle } & \multicolumn{2}{c}{ Tandem Axle } \\
\hline Single Axle Load & Axle Rate (\%) & Tandem Axle Load & Axle Rate (\%) \\
\hline 13.4 & 0.58 & 23.2 & 1.96 \\
12.5 & 1.35 & 21.4 & 3.94 \\
11.6 & 2.77 & 19.6 & 11.48 \\
10.7 & 5.92 & 17.9 & 34.27 \\
9.8 & 9.83 & 16.1 & 81.42 \\
8.9 & 21.67 & 14.3 & 85.5 \\
8.0 & 28.24 & 12.5 & 145.4 \\
7.1 & 38.83 & 10.7 & 80.4 \\
6.25 & 53.94 & 8.9 & 103.7 \\
5.4 & 168.8 & 7.1 & 120 \\
\hline
\end{tabular}

10000 vehicles annual average daily traffic (AADT) for both directions were chosen to represent traffic. Three different truck ratios of $\% 10, \% 30$ and $\% 50$ were selected. The total number of trucks was calculated from this AADT value for given truck ratios.
Then, the expected repetition for each axle type was found as given in Table 1. For the AASHTO analysis, ESAL values were found according to the truck ratios provided. And the design life is selected as 20 years. These ESAL values are presented in Table 2. 
Table 2. ESALs for each percentage of trucks for AASHTO design

\begin{tabular}{cc}
\hline Percentage of Trucks & ESAL (Million) \\
\hline$\% 10$ & 6 \\
$\% 30$ & 18.6 \\
$\% 50$ & 31 \\
\hline
\end{tabular}

In this study, the analyses were done according to $136 \mathrm{MN} \mathrm{m}-3$ (500 pci), 54.4 MN m-3 (200 pci) and 13.6 MN m-3 (50 pci) modulus of subgrade (k). The analyzes were repeated according to these three different subgrade reactions. Concrete properties are also an important influence on the design of the thickness. The pavement under the traffic loads resists the bending stress with its flexural strength. Modulus of rupture has high effect on pavement thickness design. In this study, the analyses were done according to $5.5 \mathrm{MPa}$, 4.5 MPa and $3 \mathrm{MPa}$ modulus of rupture. The analyses were carried out with a total of 27 different situations, depending on three different modulus of subgrade $(\mathrm{k})$, three different modulus of rupture and three different percentage of trucks. With repeated analyzes according to both AASHTO 1993 and PCA 1984 methods, these variables' effect on pavement thickness were tried to determine. These variables are given in Table 3 .

Table 3. Variables used in analyzes

\begin{tabular}{|c|c|c|}
\hline \multicolumn{3}{|c|}{ Variables } \\
\hline Modulus of Subgrade (k) & Percentage of Trucks & Modulus of Rupture \\
\hline $136 \mathrm{MN} \mathrm{m}^{-3}$ & $\% 10$ & $3 \mathrm{MPa}$ \\
\hline $54.4 \mathrm{MN} \mathrm{m}^{-3}$ & $\% 30$ & $4.5 \mathrm{MPa}$ \\
\hline 13.6 $\mathrm{MN} \mathrm{m}^{-3}$ & $\% 50$ & $5.5 \mathrm{MPa}$ \\
\hline
\end{tabular}

As a result of the analyses made according to AAHSTO and PCA methods, pavement thicknesses were calculated. The results of analyzes are presented in Table 4.

Table 4. Thickness results of analyzes for PCA 1984 and AASHTO 1993

\begin{tabular}{ccccc|ccccc}
\hline $\mathbf{k}$ & Trucks & $\begin{array}{c}\text { Modulus of } \\
\text { Rup. }\end{array}$ & AASHTO & PCA & k & Trucks & $\begin{array}{c}\text { Modulus of } \\
\text { Rup. }\end{array}$ & AASHTO & PCA \\
\hline pci & $\%$ & Mpa & $\mathrm{cm}$ & $\mathrm{cm}$ & $\mathrm{pci}$ & $\%$ & $\mathrm{Mpa}$ & $\mathrm{cm}$ & $\mathrm{cm}$ \\
\hline 500 & 10 & 5.5 & 20.4724 & 17.018 & 50.1 & 30 & 4.5 & 30.2514 & 28.702 \\
200.4 & 10 & 5.5 & 21.8694 & 19.05 & 500 & 30 & 3 & 34.4424 & 27.432 \\
50.1 & 10 & 5.5 & 23.1902 & 23.114 & 200.4 & 30 & 3 & 35.7124 & 30.988 \\
500 & 10 & 4.5 & 23.0886 & 19.812 & 50.1 & 30 & 3 & 36.9824 & 40.132 \\
200.4 & 10 & 4.5 & 24.4348 & 22.098 & 500 & 50 & 5.5 & 26.8478 & 20.066 \\
50.1 & 10 & 4.5 & 25.7302 & 27.178 & 200.4 & 50 & 5.5 & 28.1432 & 21.336 \\
500 & 10 & 3 & 28.956 & 26.162 & 50.1 & 50 & 5.5 & 29.4132 & 24.892 \\
200.4 & 10 & 3 & 30.2514 & 29.718 & 500 & 50 & 4.5 & 30.0228 & 21.082 \\
50.1 & 10 & 3 & 31.5214 & 38.1 & 200.4 & 50 & 4.5 & 31.2928 & 23.622 \\
500 & 30 & 5.5 & 24.6888 & 19.05 & 50.1 & 50 & 4.5 & 32.5882 & 29.21 \\
200.4 & 30 & 5.5 & 26.0096 & 20.066 & 500 & 50 & 3 & 37.2872 & 27.94 \\
50.1 & 30 & 5.5 & 27.305 & 24.384 & 200.4 & 50 & 3 & 38.5318 & 31.496 \\
500 & 30 & 4.5 & 27.6606 & 20.574 & 50.1 & 50 & 3 & 39.8018 & 41.148 \\
200.4 & 30 & 4.5 & 28.956 & 23.114 & & & & &
\end{tabular}


As seen in Figure 1 Truck Percentage has an additive effect on pavement thickness according to AASHTO method. We may also see when the concrete modulus of rupture increase, the thickness reduced according to AASHTO method.

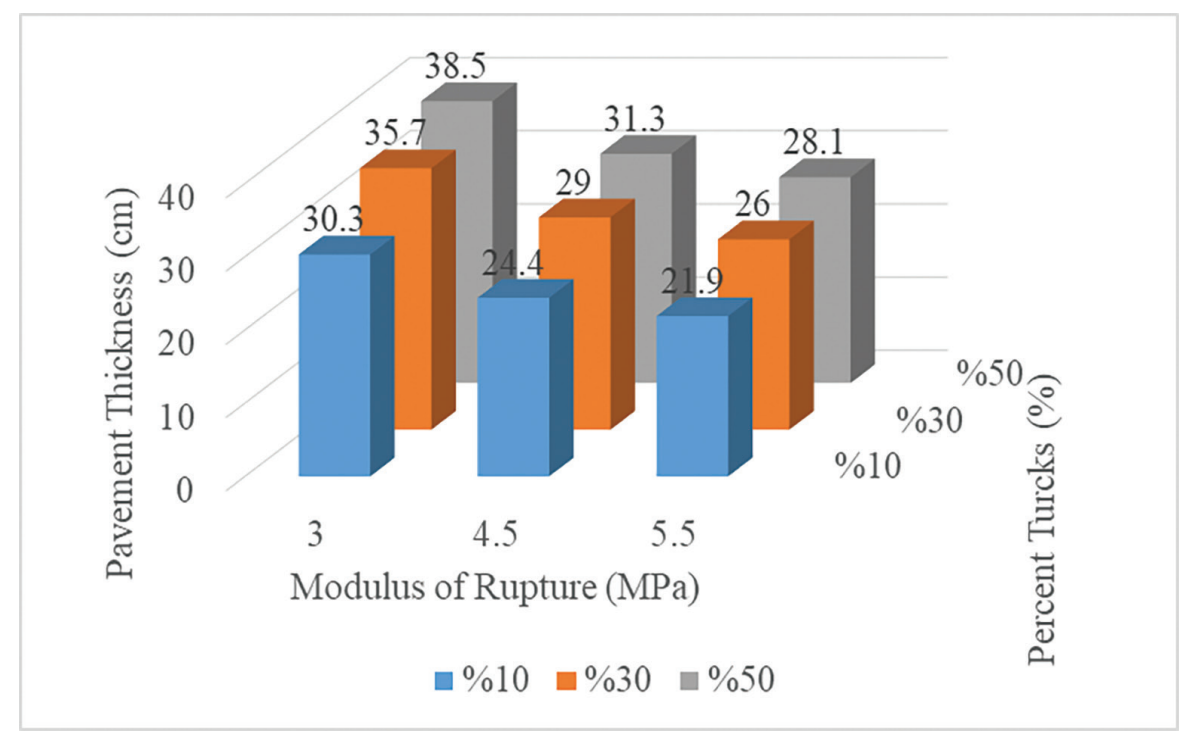

Figure 1. Design pavement thicknesses AASHTO $\left(\mathrm{k}=54.4 \mathrm{MN} \mathrm{m}^{-3}\right)$

As seen in Figure 2 Truck Percentage has an additive effect on pavement thickness according to PCA method.
We may also see when the concrete modulus of rupture increase, the thickness reduced according to PCA method.

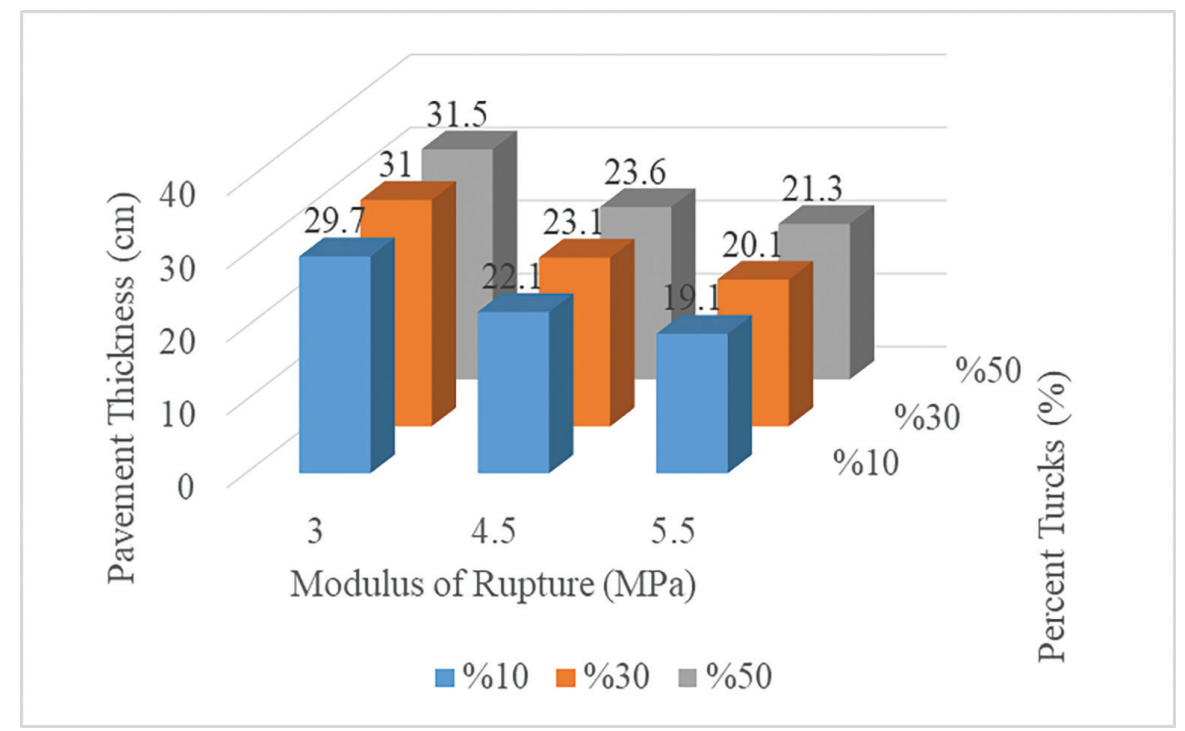

Figure 2. Design pavement thicknesses PCA $\left(\mathrm{k}=54.4 \mathrm{MN} \mathrm{m}^{-3}\right)$

As can be seen, Figure 3 according to AASHTO analysis, the improvement of the subgrade reaction has been effective in decreasing the concrete pavement thickness. 


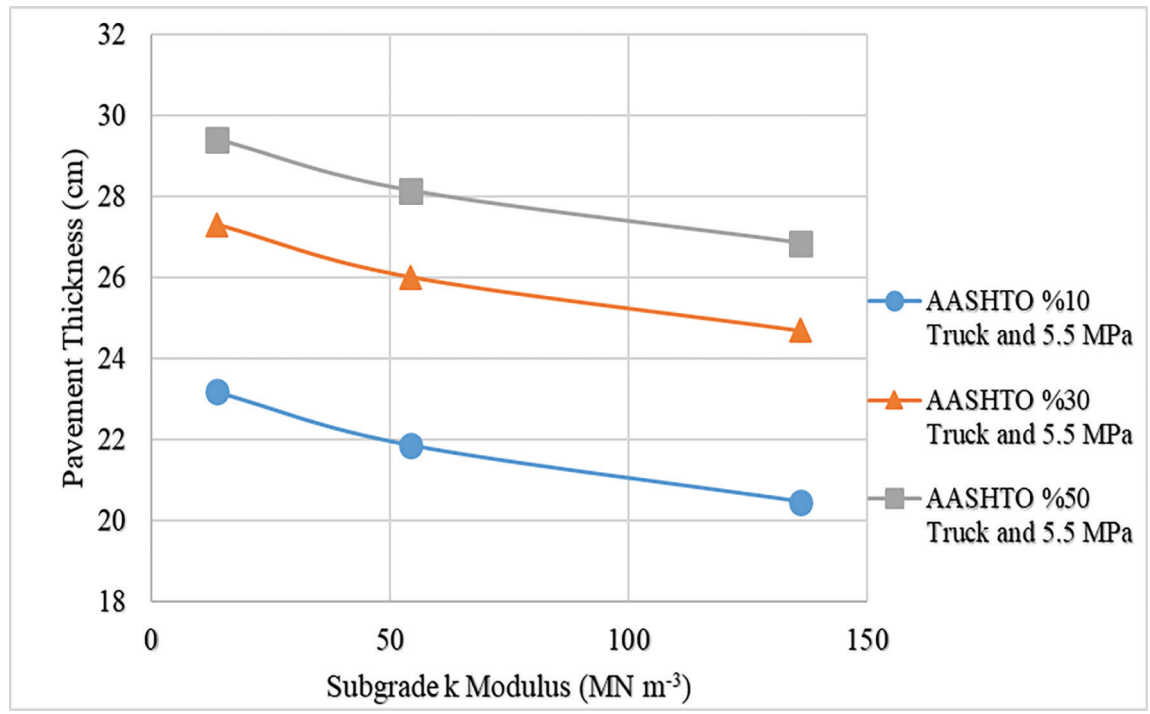

Figure 3. Correlation between pavement thickness and subgrade reaction AASHTO

As can be seen Figure 4 according to PCA analysis, the improvement of the $\mathrm{k}$ modulus has been effective in decreasing the concrete plate thickness. This mitigating effect is greater than the mitigating effect seen in the AASHTO method.

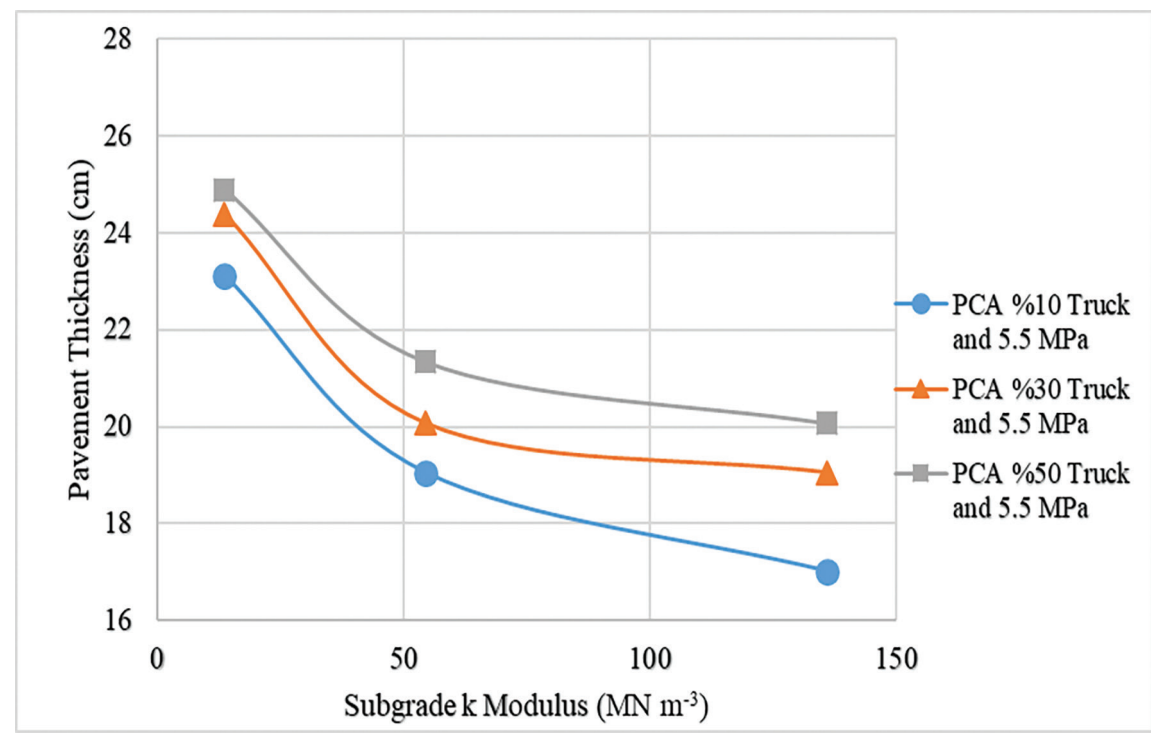

Figure 4. Correlation between pavement thickness and subgrade reaction AASHTO

\section{CONCLUSION}

As a result of the analyzes made, the subgrade reaction $(\mathrm{k})$, concrete modulus of rupture and percentage of truck in traffic has a significant effect on pavement thickness according to both design method AASHTO and PCA. It is also identified that when subgrade reaction-k and modulus of rupture is increased, the pavement thickness decrease.
It is seen under the same circumstances (traffic, the percentage of truck, modulus of rupture, subgrade reaction-k) the results obtained PCA and AASHTO design methods are in a good correlation.

Almost for all cases, the required pavement thickness is higher for AASHTO than PCA. It is seen that AASHTO method is more conservative than PCA. 
The maximum thickness difference between PCA ve AASHTO analyses occur under $\% 50$ truck traffic, 4,5 MPa modulus of rupture and $136 \mathrm{MN} \mathrm{m}^{-3}$ subgrade reaction-k. For this situation, the required thickness for AASHTO is $30 \mathrm{~cm}$ and for PCA it is $21 \mathrm{~cm}$.

For AASHTO analysis, when modulus of the rupture decreases from 5.5 $\mathrm{MPa}$ to $3 \mathrm{MPa}$, the required pavement thickness increases by $\% 41$. And for PCA analysis, when modulus of rupture decreases from 5.5 $\mathrm{MPa}$ to $3 \mathrm{MPa}$, the required pavement thickness increases by $\% 65$ especially when subgrade reaction-k is low. It is understood from these results that the PCA analysis is more sensitive to the changes modulus of rupture (especially when the subgrade reaction $\mathrm{k}$ is low).

For AASHTO analysis, when truck percentage increases from $\% 10$ to $\% 50$, the required pavement thickness increases by $\% 31$. And for PCA, when truck percentage increases from $\% 10$ to $\% 50$, the required pavement thickness increases only by $\% 18$.

These results show that the AASHTO analysis is more sensitive to changes in truck percentage.

\section{REFERENCES}

AASHTO, 1986. Guide for Design of Pavement Structures Washington DC, American Association of State Highway and Transportation Official, 440p.

AASHTO, 1993. Guide for Design of Pavement Structures. Washington DC, American Association of State Highway and Transportation Official, USA. 624 p.

Bordelon AC, Hiller JE, Roesler JR, Cervantes VG, 2015. Investigation of ESALs versus Load Spectra for Rigid Pavement Design. Airfield and Highway Pavements 488-499,

Delatte NJ, 2014. Concrete Pavement Design, Construction, and Performance. Second Edition, Crc Press, USA., 445 p.

Huang YH, 2004. Pavement Analysis and Design. Second Edition, Pearson Education Inc., 792 p.

Кðсð A, Тð€demir M, 2017. A User Friendly Software for Rigid Pavement Design, Vol.9, Issue 4, 1-16.
Lee YH, Bair JH, Lee CT, Yen ST, Lee YM, 1997. Modified Portland cement association stress analysis and thickness design procedures. Transportation Research Record Journal of the TRB, 1568: 77-88.

O'Flaherty CA, 2002. Highways: The Location, Design, Construction and Maintenance of Pavements. Fourth Edition, CRC Press, USA., 553 p.

PCA, 1966. Portland Cement Association, Thickness Design for Concrete Pavements. Skokie, IL: Portland Cement Association, USA., 32p.

PCA, 1984. Portland Cement Association, Thickness Design for Concrete Highway and Street Pavements, Engineering Bulletin EB109P. Skokie, IL: Portland Cement Association, USA. 50p.

Yoder EJ, Witczak MW, 1975. Principles of Pavement Design. John Wiley and Sons., USA., 736 p. 